\title{
COMMENTS
}

\section{The Marital Home: Equal or Equitable Distribution?}

Courts $^{2}$ and commentators ${ }^{2}$ are increasingly concerned with the treatment of the marital home ${ }^{3}$ upon divorce. In part, this reflects a recognition of divorce's impact on children." A child's best interests ${ }^{b}$ are often served by remaining in the marital home, near friends and school, rather than by moving to unfamiliar surroundings. ${ }^{B}$ Special consideration of the home is also fueled by the general trend to limit periodic payments, such as alimony and child support, and to consolidate the entire monetary settlement into

' See, e.g., In re Marriage of Duke, 101 Cal. App. 3d 152, 161 Cal. Rptr. 444 (1980); Pitsenberger v. Pitsenberger, 287 Md. 20, 410 A.2d 1052 (1980); Price v. Price, 484 P.2d 532 (Okla. 1971); Slatsky v. Slatsky, 42 Or. App. 281, 600 P.2d 885 (1979).

2 See, e.g., Perlberger, The Marital Residence-A Strategic Battleground, 81 Drck. L. Rev. 699 (1977); Wagner, Apportionment of Home Equity in Marital Dissolutions Under California Community Property Law: Is the Current Approach Equitable?, 9 Communiry Prop. J. 31 (1982); Weitzman, The Economics of Divorce: Social and Economic Consequences of Property, Alimony and Child Support Awards, 28 U.C.L.A. L. REv. 1181, 120407 (1981).

The "marital home" refers here to a home owned by at least one of the parties during the marriage that is subject to the scrutiny of the court upon divorce.

- See generally Bane \& Weiss, Alone Together, AM. Demographics, May 1980, at 11, 15 (discussing the interests of children at time of divorce); Divorce Deluge, Am. Demographics, Oct. 1981, at 11 (discussing the increasing number of children affected by divorce).

- See generally J. Goldstein, A. FreUd \& A. Solnit, Beyond the Best Interests or THE CHID (2d ed. 1979) (discussing the "best interests" standard for child custody determinations).

- A study based on interviews with divorced mothers suggests the importance parents attach to these factors. The survey reveals that divorced women make housing choices on the basis of the following factors: (1) maintaining social contacts and established school settings for the children; (2) maintaining their own social status and sense of community; (3) finding help with child care and other supportive arrangements; (4) making new social contacts for themselves; and (5) being within reasonable commuting range of jobs or job training. Anderson-Khleif, Housing Needs of Single-Parent Mothers, in BuLDING POR Women 21, 21-22 (S. Keller ed. 1981). The criteria Anderson-Khleif identifies will not always be satisfied by the marital home, but the additional emotional and financial costs incurred in a move could tip the balance in favor of retaining the marital home for the parent with custody of the children. 
the property award. ${ }^{7}$ Decreased reliance upon periodic payments relieves courts of the burden of long-term enforcement ${ }^{8}$ and avoids the implication that one spouse is not self-sufficient, ${ }^{9}$ but it leaves only the marital property to meet the parties' needs after divorce. ${ }^{10}$ Of the parties, the woman more frequently receives custody of the children $^{11}$ and is more likely to have lower income than the man. ${ }^{12}$

7 See M. Glendon, The New Family and the New Property 52-63 (1981) (discussing recent changes in the roles of alimony and property settlements); Weitzman \& Dixon, The Alimony Myth: Does No-Fault Divorce Make a Difference?, 14 FAM. L.Q. 141, 154 (1980) (noting the drop in awards of alimony after institution of no-fault divorce); Note, Property Division and Alimony Awards: A Survey of Statutory Limitations on Judicial Discretion, 50 FordhaM L. Rev. 415 (1981) (summarizing state statutory standards for property and maintenance awards). The Iowa Supreme Court explained the traditional line between alimony and property awards as follows:

Although property rights and alimony may be closely related, they are distinguishable and have differing purposes. Division of property is based on each marital partner's right to a just and equitable share of the property accumulated as the result of their joint efforts. Alimony is an allowance to the ex-wife in lieu of the husband's legal obligation to support her.

In re Marriage of Hitchcock, 309 N.W.2d 432, 437 (Iowa 1981) (citations omitted).

s See generally D. Chambers, Making Fathers Pay (1979) (describing methods of and success in enforcing child support payments). A 1975 nationwide survey revealed that of those divorced mothers awarded child support, only $47 \%$ were able to collect it regularly. $B$. Bryant, American Women Today and Tomorrow 24 (1977) (Table 3-4).

- Ruth Deech charges that alimony payments serve to "perpetuate the common law proprietary relationship of the husband and wife after dissolution of the marriage bond" and "express the superiority of the male." Deech, Why Maintenance is a Bad Bargain for all Concerned, The Times (London), Feb. 14, 1980, at 8, col. 6. The decrease in alimony awards has been a response both to the elimination of punishment as a rationale for divorce and to the recognition of a woman's capacity to support herself. Weitzman \& Dixon, supra note 7 , at 148 .

10 Some observers have suggested that the trend to value professional goodwill as a divisible asset of the marriage may circumvent this problem by disguising alimony payments as property settlements. See M. Glendon, supra note 7, at 67-68; Lurvey, Professional Goodwill on Marital Dissolution: Is it Property or Another Name for Alimony?, 52 CAL. ST. B.J. 27 (1977). This trend is quite significant, for as a study of Los Angeles divorces revealed, community property is of low value relative to wage and salary income. See Weitzman, supra note 2, at 1188-94. In one year, the average couple can earn more than the total value of their community assets, leading to the conclusion that "the spouses' earning capacity is typically worth more than the tangible assets of the marriage." Id. at 1192 (emphasis in original).

${ }^{21}$ In $1981,13 \%$ of families with children under 18 were headed by divorced or separated women, while $1 \%$ of these families were headed by a divorced father. See BurEau op the Census, U.S. Dep't of Commerce, Household and Family Characteristics: March 1981, at 7 (1982) (Table D).

- 12 In Hoffman \& Holmes, Husbands, Wives, and Divorce, in 4 Frve Thousand American Famies-Patterns of Economic Progress 23 (G. Duncan \& J. Morgan eds. 1976), divorce is identified as an accurate determinant of which individuals live in poverty. In the study, wives and children were significantly more likely to be on welfare if they experienced separation or divorce. Id. at 35. Husbands, on the other hand, experienced an average increase in spendable income after divorce. $I d$. at 28 . Other studies have yielded similar results. See D. ChAmBers, supra note 8, at 42-66; Weitzman \& Dixon, supra note 7, at 177-78. 
Separate treatment of the marital home gives courts flexibility to use the home as an item of support for the benefit of women and children needing accommodation. ${ }^{13}$

Whether courts can achieve these goals depends on the discretion available to them under state divorce law. Historically, two regimes have governed marital property in the United States, community property and common law, distinguished respectively by the principles of shared and individual ownership. ${ }^{14}$ The systems have tended to converge over time and are now united in viewing marriage as a partnership. ${ }^{15}$ Despite agreement on the partnership principle, there are two different interpretations of its meaning for property awards. The resulting dichotomy does not redraw the common law/community property line, but distinguishes between equal and equitable distribution of marital assets. ${ }^{16}$ This comment demonstrates that there are important differences in how these two systems treat the marital home. Courts in states allowing equitable distribution of marital assets are better able to give special consideration to the place of the home, while courts in states requiring equal division of assets are more likely to make awards that result in the sale of the home. The comment concludes that in any distribution system it is desirable to have a law that permits separate treatment of the home, and it identifies alternatives that may satisfy this need.

See generally S. Rawlings, Fammies Maintaingd by Female Householders 1970-79 (1980) (discussing economic and social status of families headed by women); H. Ross \& I. SAWHILL, Time of Transition: The Growth of Famiriss Headed by Women (1975) (same).

is Under the considerations mentioned in text, a strong case for special treatment of the marital home would be a divorce involving a family (a) with several children in the custody of one parent, (b) who had lived in the marital home for a few years and had established relationships in the area, (c) where a comparable replacement home could not easily be found, and (d) when sufficient funds would be available through periodic payments from the non-custodial spouse or other sources to maintain the home and prevent a forced sale soon after the divorce.

14 See Freed \& Foster, Divorce in the Fifty States: An Overview, 14 FAm. L.Q. 229, 24950 (1981); Greene, Comparison of the Property Aspects of the Community Property and Common Law Marital Property Systems and Their Relative Compatibility with the Current View of the Marriage Relationship and the Rights of Women, 13 CREIGHTON L. Rev. 71 (1979) (tracing the origins and development of each system and comparing the effects of each upon property rights at divorce and death); Comment, The Development of Sharing Principles in Common Law Marital Property States, 28 U.C.L.A. L. REv. 1269, 1272-78 (1981) (discussing origins of both systems).

1s See infra notes 17-24 and accompanying text.

16 See J. Areen, Cases and Matrrials on Famlly Law 636-37 (1978). 


\section{Description of State Marital Property Laws}

Although every state's marital property regime can be said to follow either community property or common law principles, ${ }^{17}$ the distinction may be meaningless. ${ }^{18}$ At most it will determine which property is subject to division at divorce, not how that division is to be effected. In the eight community property states, ${ }^{19}$ although only property acquired during marriage is subject to division, most property will be considered community property. ${ }^{20}$ Under the traditional common law system retained by only three states, property follows title. ${ }^{21}$ The majority of the states, however, have modified the common law title-based system so as to allow courts to apportion all the property of the divorcing parties. ${ }^{22}$ This modifica-

17 See Freed \& Foster, supra note 14.

18 See Prager, Sharing Principles and the Future of Marital Property Law, 25 U.C.L.A. L. REv. 1, 2-4 (1977); Comment, supra note 14, at 1313 ("A myth is being perpetuated that common law principles of divorce conflict with community property principles when, in fact, the two systems have grown closer and closer together."). Common law systems are currently adopting principles of sharing from community property states, while community property systems introduce concepts of equity borrowed from common law states. See J. AREEN, supra note 16, at 636-44. Painter v. Painter, 65 N.J. 196, 320 A.2d 484 (1974), has been heralded as an early sign of the breakdown between common law and community property principles. See J. AREEN, supra note 16, at 643. In that decision, the court considered the specific wording of the New Jersey equitable distribution statute and held that the legislative intent was that "all property, regardless of its source, in which a spouse acquires an interest during the marriage shall be eligible for distribution in the event of divorce." Painter, 65 N.J. at 217, 320 A.2d at 495 (emphasis in original).

19 Arizona, Ariz. Rev. Stat. AnN. § 25-211 (1956); California, Cal. Crv. Code § 5110 (West 1970 \& Supp. 1983); Idaho, Idaro Code § 32-906 (Supp. 1982); Louisiana, LA. Crv. Code Ann. art. 2336 (West Supp. 1983); Nevada, Nev. Rev. Stat. $§ 123.220$ (1979); New Mexico, N.M. Stat. Ann. \$ 40-3-12 (1978); Texas, Tex. Fam. Code Ann. \$ 5.02 (Vernon 1975); and Washington, WAsh. Rev. Code ANN. § 26.16.030 (Supp. 1983).

20 J. AREEN, supra note 16 , at 636 . The California statute defines community property as "property acquired by husband and wife, or either, during marriage, when not acquired as the separate property of either." CaL. Crv. CodE $\S 687$ (West 1982).

21 Fla. Stat. \& 61.08 (Supp. 1983); Miss. Code ANN. \& 93-5-23 (Supp. 1982); W. VA. CODE § 48-2-15 (1980). Special equity theories are employed in Florida and West Virginia to enable a species of property division. See Note, supra note 7, at 433-34 \& nn.133 \& 138. For example a person may acquire an equitable interest in property owned by his or her spouse by making contribution to that property during the marriage. Id. See also Freed \& Foster, supra note 14, at 246 (spouse may develop equity by contributions to home during marriage). In Mississippi, if a divorce is granted on grounds of irreconcilable differences, the parties must make a written agreement "for the settlement of any property rights" between them. Miss. Code ANN. $\$ 93-5-2$ (Supp. 1982). The courts must, however, exercise discretion when the parties submit their property to the judge. At that time, the judge may incorporate the agreement into the divorce decree or may modify the decree. Id.

22 Ala. Code § 30-2-51 (Supp. 1982); Alaska Stat. § 9.55.210 (Supp. 1982); ARK. Stat. ANn. § 34-1214 (Supp. 1981); Colo. Rev. Stat. § 14-10-113 (1973 \& Supp. 1982); Conn. Gen. Stat. AnN. § 46b-81 (West Supp. 1982); Ded. Code ANn. tit. 13, § 1513 (Supp. 1981); D.C. Code Ann. § 16-910 (1981); Ga. Code Ann. § 19-2 (1982); Hawan Rev. Stat. § 580-47 (Supp. 
tion of the common law system reflects changed ideas of economic fairness which dictate that the homemaker's nonmonetary contributions to the marriage be recognized and acknowledges that title is an inaccurate indicator of participation in the marriage..$^{23}$ In this manner "common law" states have accepted the view of marriageas-partnership that underlies the community property systems. ${ }^{24}$

The general acceptance of the partnership model has by no means given rise to uniform laws as to how marital property, once defined, ${ }^{25}$ is to be divided. The states have adopted two different methods, equal and equitable distribution of marital property. ${ }^{26}$

1982); Marriage and Dissolution Act $\S 503$, IrL. Rev. STAT. ch. 40, 503 (1981); IND. Cods AnN. § 31-1-11.5-11 (Burns 1980); IoHa Code ANn. § 598.21 (West 1981); Kan. Stat. AnN. § 60-1610(b) (Supp. 1982); Ky. Rzv. STAT. ANN. $\$ 403.190$ (Bobbs-Merrill Supp. 1982); ME. Rev. Stat. Ann. tit. 19, § 722-A (1964); Mass. Ann. Laws ch. 208, § 34 (Michie/Law. Co-op. Supp. 1983); Mrch. Comp. Laws AnN. \& 552.19 (1967 \& Supp. 1982); Minn. Stat. Ann. § 518.58 (West Supp. 1983); Mo. Ann. Stat. $\$ 452-330$ (Vernon Supp. 1983); Neb. Rzv. Stat. § 42-365 (1978); N.H. Rev. Stat. Ann. § $458: 19$ (1968); N.J. Stat. Ann. § 2A:34-23 (West Supp. 1982); N.Y. Dom. RzL. LAF § 236(B) (McKinney Supp. 1982); N.C. Gen. Stat. § 5020 (Supp. 1981); Oho Rev. Code AnN. § 3105-18 (Page 1980); OkLa. Stat. ANN. tit. 12, § 1278 (West Supp. 1982); OR. Rzv. Stat. § 107.105 (1981); PA. Stat. Ann. tit. 23, § 401 (Purdon Supp. 1982); R.I. GRN. Laws § 15-5-16.1 (Supp. 1982); S.D. Codirizd Laws ANN. § 25-4-44 (1976); Trnn. Codr ANn. § 36-821 (Supp. 1982); Utah Codr AnN. § 30-3-5 (Supp. 1981); VT. Stat. ANN. tit. 15, \& 751 (Supp. 1982); VA. Code \& 20-107.3 (Supp. 1982); Wis. Stat. AnN. \& 767.255 (West 1981 \& Supp. 1982); Wyo. StaT. \& 20-2-114 (Supp. 1982).

${ }^{23}$ See Comment, supra note 14, at 1270-71 \& n.11. Most recently, New York, Act of June 19, 1980, ch. 281, § 9, 1980 N.Y. Laws 1225 (codified at N.Y. Dom. RBL. LAw § 236(B)(5)(d)(6) (McKinney Supp. 1982)), North Carolina, Act of Oct. 1, 1981, ch. 815, \& 1 (codified at N.C. GEN. Stat. $\$ 50-20(c)$ (6) (Supp. 1981)), and Pennsylvania, Act of April 2, 1980, No. 26, § 401, 1980 Pa. Laws 63 (codified at PA. Stat. Ann. tit. 23, § 401(d) (Purdon Supp. 1982)), have retired title-based systems in favor of statutes recognizing the efforts of homemakers.

34 See Lay, Community Property: Its Origin and Importance to the Common Law Attorney, 5 J. FAM. L. 51 (1965). See also Cherry v. Cherry, 66 Ohio St. 2d 348, 353-56, 421 N.E.2d 1293, 1297-99 (1981) (discussing partnership principle and applying it to common law regime of property distribution); Dullea, 'Equitable Distribution' Divorce: Redefining Who Gets What, N.Y. Times, June 10, 1980, at B19, col. 1 (describing new New York law, see supra note 23 , as being based on partnership theory).

25 Comment, supra note 14, at 1282-84 (identifying three general methods of implementing sharing principles in common law states: (1) deferred community property, (2) equitable distribution of property, and (3) expanded alimony). The problem of identifying separate and marital property is not discussed here. For a general view of the law in this area with specific reference to the home, see Wagner, supra note 2 . This issue is also implicated in awards of pensions, goodwill, and professional licenses. M. GLENDON, supra note 7, at 67-68.

16 See supra note 16 and accompanying text. Black's LAw Dictionary 483 (5th ed. 1979) defines "equitable distribution" as "[n]o-fault divorce statutes in certain states (e.g. New Jersey) [that] grant courts the power to distribute equitably upon divorce all property legally and beneficially acquired during marriage by husband and wife, or either of them, whether legal title lies in their joint or individual names." The definition is not entirely accurate, as some states with fault criteria allow for distribution of all marital property, see, e.g., Marriage and Dissolution Act § 503, ILL. Rev. StaT. ch. 40, § 503 (1981), and therefore 
Equal division generally means awarding precisely equivalent shares of marital property with little, if any, judicial discretion to deviate from that norm. ${ }^{27}$ Equitable distribution allows for significant judicial discretion; equity is the ultimate standard for any property award..$^{28}$

Equal division of property upon divorce is an accepted part of the system in at least twelve states, ${ }^{29}$ ranging from judicial presumption to statutory mandate. The community property states of California, ${ }^{30}$ Idaho, $^{31}$ and Louisiana ${ }^{32}$ require equal division of marital property. In addition, New Mexico's community property statute has been construed to require equal division of marital property. ${ }^{33}$ A statutory presumption in favor of equal division is exercised in the "common law" states of Arkansas, ${ }^{34}$ North Carolina, ${ }^{36}$ and Wisconsin..$^{38}$

may be classified as equitable distribution states. The word "equitable" is not always used, see, e.g., Kan. STAT. ANN. \& 60-1610(b)(1) (Supp. 1982) ("just and reasonable"); neither is the word "equal." In Arizona, a community property state, the requirement of "equitable" division, ARIz. REv. STAT. ANN. \$ 25-318 (Supp. 1982), has been interpreted to require "equal" division. See infra notes $44-49$ and accompanying text.

${ }^{27}$ See infra notes 59-96 and accompanying text.

28 See infra notes 97-104 and accompanying text.

29 See infra notes 30-57 and accompanying text.

so Cal. Crv. Code $\S 4800$ (West Supp. 1983). The statute provides in pertinent part:

(a) Except upon the written agreement of the parties, or on oral stipulation of the parties in open court, the court shall ... divide the community property and the quasicommunity property of the parties, including any such property from which a homestead has been selected, equally. ... .

(b) Notwithstanding subdivision (a), the court may divide the community property and quasi-community property of the parties as follows:

(1) Where economic circumstances warrant, the court may award any asset to one party on such conditions as it deems proper to . . . effect a substantially equal division of the property.

s1 IDAHo CoDE § 32-712(1)(a) (Supp. 1982) ("Unless there are compelling reasons otherwise, there shall be a substantially equal division in value, considering debts, between the spouses.").

s2 LA. Crv. Code Ann. arts. 155, 159, 160 (West Supp. 1982).

ss See Michelson v. Michelson, 86 N.M. 107, 520 P.2d 263 (1974) (construing N.M. STAT. ANN. \& 40-4-7 (1978)).

34 Ark. Stat. AnN. § 34-1214(A)(1) (Supp. 1981).

ss N.C. Gen. STAT. \& 50-20(c) (Supp. 1981): "There shall be an equal division by using net value of marital property unless the court determines that an equal division is not equitable. If the court determines that an equal division is not equitable, the court shall divide the marital property equitably." See also Knott v. Knott, 52 N.C. App. 543, 546-47, 279 S.E.2d 72, 75 (1981) (error to order unequal division); Note, Is There a Need for Equitable Distribution of Property upon Divorce in North Carolina?: Leatherman v. Leatherman, 11 N.C. CENT. L.J. 156, 160 (1979) (discussing changes from title-based system to present North Carolina law).

se Wrs. Stat. ANN. § 767.255 (West $1981 \&$ Supp. 1982). ("The court shall presume that all other property is to be divided equally between the parties, but may alter this distribu- 
In Texas, equal division of marital assets has been imposed ${ }^{37}$ despite statutory language directing the courts to "order a division ... in a manner that the court deems just and right." 1976 , the "just and right" test was interpreted to allow courts to divest divorcing spouses of property not held jointly during marriage. ${ }^{39}$ The Texas Supreme Court's opinion in Eggemeyer v. Eggemeyer, ${ }^{40}$ however, found the practice to be an unconstitutional divestment of property. ${ }^{41}$ In the aftermath of Eggemeyer, commentators urged a shift to California's equal distribution system, ${ }^{42}$ primarily because consideration of "factors unrelated to the ownership rights of the respective spouses is contradictory to the basic policy underlying the use of partition between the owners of undivided interests in property."

tion without regard to marital misconduct after considering: [the length of the marriage, the desirability of awarding the home to the custodial parent, etc.]"). See Bartke \& Zurvalec, The Low, Middle and High Road to Marital Property Law Reform in Common Law Jurisdictions, 7 CoMmunity Prop. J. 200, 221-226, 228 (1980) (claiming that the Wisconsin statute adopts a community property model); Younger, Marital Regimes: A Story of Compromise and Demoralization, Together with Criticism and Suggestions for Reform, 67 CoRnklL L. Rev. 45, 74 (1981) (suggesting that Arkansas and Wisconsin come closer than other common law states to recognizing marriage as a true partnership).

${ }^{27}$ See Campbell v. Campbell, 625 S.W.2d 41 (Tex. Civ. App. 1981).

se Tex. Fam. Code ANN. $\S 3.63$ (Vernon Supp. 1981). The statute also directs the court to have "due regard for the rights of each party and any children of the marriage." Id.

3" Castleberry, Constitutional Limitations on the Division of Property Upon Divorce, 10 St. MARY's L.J. 37, 38-39 (1978). The statutory provision enabling a divorce court to divide and dispose of the property of the parties was first enacted in 1841. Act of Jan. 6, 1841, \& 4, 1841 Tex. Gen. Laws 20. In Hailey v. Hailey, 160 Tex. 372, 376, 331 S.W.2d 299, 303 (1960), this was interpreted to mean only separate property. The statutory provision that was enacted as $\S 3.63$ of the Texas Family Code omitted any reference to separate property, causing considerable confusion. Compare Ramirez v. Ramirez, 524 S.W.2d 767, 768 (Tex. Civ. App. 1975) ( 33.63 did not change former law) with Baxla v. Baxla, 522 S.W.2d 736, 738 (Tex. Civ. App. 1975) (holding that $\S 3.63$ changed law) and Wilkerson v. Wilkerson, 515 S.W.2d 52, 56-57 (Tex. Civ. App. 1974) (same).

10 554 S.W.2d 137 (Tex. 1977). Eggemeyer specifically approved Ramirez and determined that $\S 3.63$ was enacted as a codification of existing law. Id. at 139,142 .

${ }^{41}$ Id. at 139-40. The Eggemeyer case is discussed thoroughly in Castleberry, supra note 39.

42 See Castleberry, supra note 39, at 51; Comment, Division of Marital Property on Divorce: What Does the Court Deem "Just and Right?," 19 Hous. L. REv. 503, 524-25 (1982).

4s Castleberry, supra note 39, at 51. The Eggemeyer decision does, however, leave room for judicial discretion in extreme cases. One aspect of this discretion is the power of the courts to consider children's needs when dividing property. Since the enactment of the Texas Code in 1841, "the property division statute has provided that the rights of children shall be considered in making the division." McKnight, Family Law: Husband and Wife, 35 Sw. L.J. 93, 138 (1981) (footnote omitted). Most recently in Young v. Young, 609 S.W.2d 758 (Tex. 1980), the Texas Supreme Court held that the right of support of a disabled, unmarried adult child in the care of a spouse could be considered in making a division of property in divorce. Id. at 760. Apparently, occupancy of the separate home of one spouse in 
Arizona is experiencing a similar trend toward equal division.44 The Arizona Supreme Court in 1976 in Hatch $v$. Hatch ${ }^{45}$ held that unequal property distribution is an unconstitutional deprivation of the wife's vested property interest in the community assets. ${ }^{46}$ Though there was some speculation that equitable considerations might enable courts to adjust awards, ${ }^{47}$ the Arizona Court of Appeals rejected this idea in Lee $v . L e e^{48}$ and required that any award be "substantially equal." Similar debates surrounded the adoption in New York ${ }^{50}$ and Pennsylvania ${ }^{51}$ of new domestic relations statutes in $1980 .{ }^{52}$ Although both states enacted laws in the equita-

some cases may be awarded to the custodial spouse. See McKnight, supra, at 139.

4s See Comment, Arizona Property Division Upon Marital Dissolution, 1979 ARIz. ST. L.J. 411, 416-17.

4s 113 Ariz. 130, 547 P.2d 1044 (1976).

4s Id. at 134, 547 P.2d at 1048. See Comment, supra note 44, at 414-15. Legislation in 1973 substituted "equitably" for "just and right" as the standard for property division. Id. at 412. Though Hatch was decided under the pre-1973 "just and right" standard, the courts have not recognized a change in the law-_equitably" has been construed as a variation of "just and right." Id. at 417.

67 See Comment, supra note 44 , at 417 , which states that "there is an established pattern of wide discretion in dividing the property, so long as the trial court begins from the premise that the division should be substantially equal, a premise which can only be overcome with sound reasons for the division." Id. But see Fong v. Fong, 121 Ariz. 298, 589 P.2d 1330 (Ct. App. 1978) (extreme need of wife not sufficient to rebut presumption of equal division).

48133 Ariz. 118, 649 P.2d 997 (Ct. App. 1982).

40 Id. at 121,649 P.2d at 1000 ("The only inherent limitation on the power of the trial court to apportion community property is that the division, in the final analysis, must result in a substantially equal distribution which neither rewards nor punishes either party." (citation omitted)).

so See Foster, Commentary on Equitable Distribution, 26 N.Y.L. ScH. L. REv. 1, 34 (1981); Note, New York's Equitable Distribution Law: A Sweeping Reform, 47 Brookz YN L. Rev. 67, 77-78 (1980); Recent Developments, Equitable Distribution in New York, 45 ALB. L. REv. 483 (1981). The New York law replaces a title-based system. See N.Y. Dom. REL. LAW § 236 (McKinney 1977), amended by N.Y. DoM. REL. LAw § 236 (McKinney Supp. 1981).

s1 Fingerman, Problems, Procedures and Possibilities Under the New Divorce Code, 51 PA. B.A.Q. 192 (1980); Lippincott, Highlights of Pennsylvania's New No-Fault Divorce Law, 51 PA. B.A.Q. 185 (1980); Raphael, Family Law, 52 PA. B.A.Q. 16 (1981).

${ }^{82}$ Freed \& Foster, supra note 14, at 230, ironically observe that Pennsylvania women's groups lobbied for equal division, while in New York equal division was opposed by the state chapter of N.O.W. In New York, Doris Sassower, a divorce lawyer, argued that the adoption of equitable distribution over an equal presumption would "throw our courts into chaos" and provide no guidance to parties settling out of court. See Sassower, Looking Anew for Fair Divorce Law, N.Y. Times, May 11, 1980, $\$ 22$, at 18, col. 1. In response, supporters of equitable distribution cited the often inequitable results in California. See Rankin, Property Settlements, N.Y. Times, May 3, 1980, § 1, at A30, col. 1. The New York legislators were offered a clear choice, as bills representing both positions were on the floor for consideration at the same time. See Sassower, supra. 
ble distribution mode, ${ }^{63}$ Pennsylvania courts have informally adopted a presumption of equal division, ${ }^{54}$ and New York courts have also favored equal division.ss Iowa courts have done the same, ${ }^{68}$ but both Iowa and New York allow the presumption to be overcome in a well-defined category of cases where equal division is considered inequitable. ${ }^{57}$

\section{The Effects of Equal and Equitable Property Division Laws on the Disposition of the Marital Home}

\section{A. Equal Division and the Marital Home}

1. California. In Duke v. Duke, ${ }^{68}$ a California Court of Appeal panel articulated why the marital home should be treated differently from other marital property:

The value of the family home to its occupants cannot be measured solely by its value in the marketplace. The longer the occupancy, the more important these non-economic factors become and the more traumatic and disruptive a move to a new environment is to children whose roots have become firmly entwined in the school and social milieu of their neighborhood. ${ }^{59}$

ss See N.Y. Dom. Rel. Law § 236 (McKinney Supp. 1981); PA. Stat. ANn. tit. 23, §§ 401-402 (Purdon Supp. 1982).

st See, e.g., Paul W. v. Margaret W., 8 FAM. L. REP. (BNA) 3013, 3014 (Allegheny County Ct. Dec. 1, 1981).

ss See, e.g, Majauskas v. Majauskas, 110 Misc. 2d 323, 328, 441 N.Y.S.2d 900, 903 (Sup. Ct. 1981) ("Enactment of the new Equitable Distribution Law in New York State allows the courts to 'go behind the scenes' of a marriage and hopefully give both spouses an equal division of the parties' marital property.").

se See, e.g., Schissel v. Schissel, 292 N.W.2d 421, 423 (Iowa 1980) ("We have rejected a mechanical rule that each spouse must receive one-half of the marital assets, but we have recognized that equal division of marital property is often equitable." (citations omitted)).

${ }^{87}$ See Schantz v. Schantz, 163 N.W.2d 398, 405 (Iowa 1968) (formulating exceptions to equal division, later incorporated into statute at IOWA CoDE $\$ 598.21$ (1981)); Wobser v. Wobser, 458 N.Y.S.2d 113, 114 (App. Div. 1982) ("Only where one spouse has demonstrated an overriding need to occupy the marital premises, is an award of exclusive possession proper." (citations omitted)); Wurm v. Wurm, 87 A.D.2d 590, 591, 447 N.Y.S.2d 758, 759 (1982) (overriding need for unequal division since divorced husband had history of failure to fulfill financial obligations).

ss 101 Cal. App. 3d 152, 161 Cal. Rptr. 444 (1980).

so Id. at 155-56, 161 Cal. Rptr. at 446 . The court found that "[t]he economics of obtaining equivalent housing for a minor child's welfare is certainly well within the legislative intent expressed by the statute." Id. at 157, 161 Cal. Rptr. at 446 (citing Hermann v. Hermann, 84 Cal. App. 3d 361, 148 Cal. Rptr. 550 (1978)). The court remanded the case for consideration of these factors and for possible deferral of the sale of the home. Id. at 160, 161 Cal. Rptr. at 448. 
Nevertheless, California requires equal division of the marital assets almost without exception. ${ }^{60}$ According to the courts, equal division was "the fundamental objective of the Legislature" adopting the Family Law Act in 1969.82 If "economic circumstances" ${ }^{83}$ warrant, awards need not be in kind, but the court may award any asset to one party only on conditions that will lead to a substantially equal division of property. ${ }^{64}$ Thus, the approach to home awards outlined in the Duke opinion seems without support in the Family Law Act. Moreover, the case law belies the Duke assumption that non-economic factors will be considered.

A California Court of Appeal's discussion in Juick v. Juick ${ }^{65}$ demonstrates the problems of reconciling equal division and preservation of the marital home. The trial court awarded custody of the two children along with the marital home to the wife. The wife was required to make monthly payments to the husband for his share of the equity in the house. ${ }^{68} \mathrm{He}$ appealed, objecting that the division of assets was not immediate and that there was no provision for the effect of inflation on the value of the wife's payments to him. ${ }^{67}$ The court of appeal held that he had no right to the immediate enjoyment of an asset, but found that deferred enjoyment

oo See CAL. Crv. Code $\S 4800$ (West Supp. 1983). The statute is reprinted in part supra note 30 .

'1 Juick v. Juick, 21 Cal. App. 3d 421, 427, 98 Cal. Rptr. 324, 329 (1971) ("Under the Family Law Act clearly the ideal is a mathematically equal division." (footnote omitted)). See also Tammen v. Tammen, 63 Cal. App. 3d 927, 927, 134 Cal. Rptr. 161, 162 (1976) (home awarded to wife on execution of promissory note; remanded as unequal since note's face value failed to take account of uncertainty, inflation, and concerns of ownership).

${ }_{\text {B2 }}$ Act of Sept. 5, 1969, ch. 1608, § 8, 1969 Cal. Stat. 3333 (codified at CaL. Crv. Code § 4800 (West Supp. 1983)). This Act was the first of a flurry of statutes instituting "no fault" divorce. Prior to the Act, property awards reflected the guilt or innocence of the divorcing parties. See Goddard, A Report on California's New Divorce Law: Progress and Problems, 6 FAM. L.Q. 405, 406 (1972). The Family Law Act introduced principles of "partnership" and imposed fifty-fifty division. CAL. Crv. CoDE $\$ 4800$ (West 1970 \& Supp. 1983).

"s CaL. Crv. Code $\S 4800$ (West Supp. 1983). The custody of minor children qualifies as an "economic circumstance." Emmett v. Emmett, 109 Cal. App. 3d 753, 169 Cal. Rptr. 473 (1980) (award of residence to wife balanced by award of pension to husband). This discretion has been confined to situations where an asset cannot be divided without impairment of the principal. Brigden v. Brigden, 80 Cal. App. 3d 380, 391, 145 Cal. Rptr. 716, 724 (1978).

3. CAL. Crv. Code $\S 4800$ (West Supp. 1983). The trend to value goodwill may be a response to the need to balance awards of one large asset, such as the marital home, with an award to the other spouse of equal value. See M. GLENDon, supra note 7, at 67-68. See also supra note 10.

ss 21 Cal. App. 3d 421, 98 Cal. Rptr. 324 (1971).

${ }^{38}$ Id. at 423-24, 98 Cal. Rptr. at 326 . The parties had been married 10 years and the children were aged seven and nine. In addition to making payments to her husband for his share of the equity in the house, the wife assumed a $\$ 10,407$ encumbrance on the house. A lien on the property secured the payments to the husband. Id.

${ }^{67}$ Id. at 424,98 Cal. Rptr. at 326-27. 
was relevant in assessing the equality of the division. ${ }^{88}$ As to the effects of inflation, the court held that "when monies to be acquired by one's spouse in the future are injected as an element, there is no reason why the effort should not be made to reach mathematical equality."69 Applying this rather strict and literal test of equal division, the court remanded the case for further findings and, if necessary, a modification of the installment arrangement..$^{70}$

The debilitating effect of this strict equality requirement on efforts to award the marital home to the party with custody of minor children becomes more apparent in cases decided after Juick. In Holmgren $v$. Holmgren, ${ }^{71}$ upon the breakup of a twenty-oneyear marriage, the wife received custody of the minor child.72 The wife claimed that the home was her only "real security" and that its sale would be unreasonable under the circumstances, but the court applied the equal division standard. Since the wife was financially unable to purchase the husband's share of the house, the house was sold and the proceeds divided. ${ }^{74}$ In Gonzales $v$. Gonzales, ${ }^{75}$ the trial court had awarded the use and possession of the marital home to the wife, but left title to the property in the husband and wife as tenants in common. ${ }^{76}$ The California Court of Appeal determined that the trial court awarded the home to the wife "because economically, based on its then determination of the respective property interests, and environmentally, it felt it was best for her and the children."77 Nevertheless, the arrangement was remanded for modification in compliance with the equality standard..$^{78}$

After Holmgren and Gonzales, only those arrangements that are arithmetically equal appear to be able to withstand a court's

es Id. at 424-25, 98 Cal. Rptr. at 327.

69 Id. at 428,98 Cal. Rptr. at 330.

70 Id. at 430-31, 98 Cal. Rptr. at 331-32.

7160 Cal. App. 3d 869, 130 Cal. Rptr. 440 (1976).

${ }^{72} \mathrm{Id}$. at $871-72,130 \mathrm{Cal}$. Rptr. at 441 . The wife apparently had little independent income and had failed to find work due to lack of education. Id.

${ }^{73}$ Id. at 872,130 Cal. Rptr. at 442 .

"Id. at 873,130 Cal. Rptr. at 442 .

75 116 Cal. App. 3d 556, 172 Cal. Rptr. 179 (1981).

76 Id. at 560, 172 Cal. Rptr. at 181 . The husband challenged the cotenancy requirement and also argued that the order was improper insofar as the trial court characterized it as an award of additional child support. Id. at 565, 172 Cal. Rptr. at 184. See generally Annot., 2 A.L.R.3D 596 (1965 \& Supp. 1982) (discussing the propriety of an undivided award for both child support and spousal maintenance).

${ }_{77} 116 \mathrm{Cal}$. App. 3d at 565, $172 \mathrm{Cal}$. Rptr. at 184.

78 Id. at 565-66, 172 Cal. Rptr. at 184. 
scrutiny on appeal. Since the home is often the couple's largest asset, it can seldom be balanced off by other awards when equal division is mandated. Thus the requirements of equal division inhibit outright awards of the marital home to either party, even if judges recognize a need to preserve the home.

2. Equal Division in Other States. Through statute and judicial interpretation, other states have adopted equal division standards similar to California's. ${ }^{79}$ These laws, too, may pose obstacles to treating the marital home differently from other marital property. For example, the Idaho statute allows deviation from equal division only for "compelling reasons." the law, citing California precedent, places the burden of persuading the trial court to award other than a fifty-fifty distribution on the party asserting the need for inequality. ${ }^{81}$ This burden is disproportionately strong because the spouse requiring additional support may have fewer resources with which to combat an unfavorable presumption.

The effect of a strong presumption of absolute equality is apparent in Wisconsin case law. In Drews $v$. Drews, ${ }^{82}$ for example, because there was "no clear case for a property share in excess of $50 \%$," the Wisconsin Court of Appeals rejected the trial court's decision to award sixty percent of the marital property to the wife and forty percent to the husband. ${ }^{83}$ Yet the wife had custody of the couple's child and a full-time salary considerably less than half of her husband's. ${ }^{84}$ In another Wisconsin case, the court imposed a fifty-fifty split of the marital assets despite the fact that the effect of the division was to force a sale of the marital home. ${ }^{85}$

3. The Effects of Equal Division in California. A recent sur$v^{8}{ }^{86}$ illustrates the effect the equal division system in California

79 See supra notes 29-57 and accompanying text.

BO IDAHo CoDE $\S 32.712(2)$ (Supp. 1982).

11 See Guy v. Guy, 560 P.2d 876 (Idaho 1977) (equal allocation of community property appropriate in absence of factors requiring otherwise).

82 Wis. 2d 916, 274 N.W.2d 905 (Ct. App. 1979) (unpublished limited precedent opinion available in full August 8,1983 , on LEXIS, States Library, Wisc. File).

s3 Id.

Id.

${ }^{85}$ Glatz v. Glatz, 92 Wis. 2d 909, 286 N.W.2d 646 (1979) (unpublished limited precedent opinion available in full August 8, 1983, on LEXIS, States Library, Wisc. File).

so Weitzman, supra note 2. Weitzman collected and analyzed court records from San Francisco and Los Angeles Counties in 1968, 1972, and 1977. Forty-four family court judges were interviewed in 1974 and 1975, and 26 completed questionnaires in 1981 . In 1974 and 1975 Weitzman further interviewed 169 matrimonial attorneys in Los Angeles and San Francisco, and in 1974 she interviewed 114 recently divorced men and 114 recently divorced women in the Los Angeles area. She stratified the latter sample by length of marriage and 
has had on the disposition of the marital home after divorce. Forty-six percent of those surveyed owned or had some equity in a home, as compared to an eleven percent ownership rate for other real estate and businesses. ${ }^{87}$ Additionally, families with minor children were found more likely to own homes than were childless couples; only thirty-three percent of couples without children were homeowners, while sixty-five percent of families with young children owned a home. ${ }^{88}$

Data on home awards in California were compiled before and after the adoption of the Family Law Act and the equal division requirement. ${ }^{80}$ The study indicates that with the implementation of no-fault divorce and the equal division standard in $1969,{ }^{90}$ more homes were divided equally: from one-fourth of the homes in 1968 to one-third in 1977.91 There was a corresponding decline in the percentage of cases in which the greater part of the home equity was awarded to the wife; ${ }^{22}$ the presence of minor children did not increase the likelihood that the wife would be awarded the marital home. ${ }^{93}$ The number of cases in which there was an explicit order to sell the home rose from about one in ten in 1968 to about one in three in 1977. ${ }^{94}$ By 1977, in most cases in which the home was a marital asset subject to division, it was sold rather than awarded intact. ${ }^{95}$ The study concludes that concern over "the effects of a forced sale of the home on the children appears to be well-founded since our data reveal that $66 \%$ of the couples who were forced to sell their homes had minor children."196

socioeconomic status. Id. at 1186-87. See also Weitzman \& Dixon, supra note 7, at 144-45. 87 Weitzman, supra note 2, at 1193, 1196. The median value of the homes in 1977-1978 was near $\$ 33,000$. Id. at 1193 .

is. at 1205 n.77.

"Id. at 1186-87.

- See generally Krom, California's Divorce Law Reform: An Historical Analysis, 1 PAc. L.J. 156 (1970) (examining the legislative history of California's Family Law Act of 1969, which abandoned the fault theory of divorce and implemented the equal division standard of property allocation); Weitzman \& Dixon, supra note 7 (examining the effects of California's no-fault provision).

"Weitzman, supra note 2, at 1204-05. "Equal division" can mean either joint ownership by the parties or sale and division of proceeds. Id. at 1204 .

" Id. This finding supports the earlier observation in Weitzman \& Dixon, supra note 7, that "under the new law wives were less likely to receive the house [and] furnishings ... and more likely to take on obligations to repay part of the community debts." Id. at $184 \mathrm{n} .85$ (emphasis in original).

"Weitzman, supra note 2, at 1205.

M Id.

9 Id.

* Id. The report indicates that a substantial proportion of lawyers and judges in Califormia perceive inequity in the equal division system. Though over $80 \%$ of those interviewed 


\section{B. Equitable Division and the Marital Home}

Equitable division regimes are characterized by flexible statutory guidelines, which can accommodate special consideration of the home. ${ }^{97}$ In equitable division states, awards of the home's use or possession have been based on the need to "retain the stability of the family home for the [custodial spouse] and minor children," "the financial and emotional needs of the children," need for shelter, ${ }^{100}$ " 'the adverse effect a change in surroundings often has on children of tender years,' "101 the cost of arranging for sale depleting resources available for support, ${ }^{102}$ and simply the best interests of the children involved. ${ }^{103}$ When an award of the home or its use has not been made, the reasons given are usually economic - that there was too little property of the marriage to enable equitable distribution at all. ${ }^{104}$

The law of Connecticut exemplifies the flexibility of an equitable division regime. Connecticut adopted no-fault divorce in 1973 while retaining the theory that property held during the marriage

agreed that equal division was basically fair, close to $40 \%$ thought that judges should be allowed more discretion in dividing community property, specifically the marital home. Id. at 1200. Attorneys who concluded that there was enough discretion in the system pointed to the role of judges in assigning value to community property and setting support awards. Id.

${ }^{97}$ See, e.g., Dex. Cone ANN. tit. 13, § 1513 (1981); Marriage and Dissolution Act § 503, ILI. REv. Stat. ch. 40, § 503 (1981); Iowa Code ANn. § 31-1-11.5-11 (Burns 1980).

ss Collette v. Collette, 177 Conn. 465, 470, 418 A.2d 891, 894 (1979) (upholding award of husband's interest in jointly-owned family home).

90 Schaeffer v. Schaeffer, 184 N.J. Super. 423, 428, 446 A.2d 537, 539 (1982). See also Paul W. v. Margaret W., 8 FAM. L. REP. (BNA) 3013 (Allegheny County Ct. Dec. 1, 1981) (award of home to minimize disruption of minor child's life).

100 See, e.g., Lavery v. Lavery, 208 Kan. 603, 492 P.2d 1311 (1972) (order other than award of home would leave mother and children without shelter); Price v. Price, 484 P.2d 532 (Okla. 1971) (now that wife did not have custody, court no longer recognized need to maintain a home for the children); Stearns v. Stearns, 80 S.D. 443, 126 N.W.2d 124 (1964) (award of home to custodial parent to provide a home for the children).

${ }^{102}$ Slatsky v. Slatsky, 42 Or. App. 281, 284, 600 P.2d 885, 886 (1979) (quoting Johnson v. Johnson, 245 Or. 10, 16, 419 P.2d 28, 30-31 (1966)) (minimum disruption in children's lives is an important factor in property division).

${ }^{102}$ See Tomko v. Tomko, $69 \mathrm{~Pa}$. D. \& C.2d 466, 472 (Bucks County Ct. 1975).

103 See, e.g., Molnar v. Molnar, 110 Mich. App. 622, 313 N.W.2d 171 (1981) (award of home to custodial parent for benefit of minor child no longer justified after child's death); Vanet v. Vanet, 544 S.W.2d 236, 240 (Mo. Ct. App. 1976) (courts have broad discretion to consider statutory mandate concerning welfare of minor children when awarding home); Johnson v. Lowary, 81 S.D. 202, 132 N.W.2d 823 (1965) (court may assign use and possession of home as welfare and best interests of children require).

104 See, e.g., Swinney v. Swinney, 419 N.E.2d 996 (Ind. Ct. App. 1981) (custody alone will not support award of a residence when residence is sole marital asset); Dowie v. Dowie, 215 N.W.2d 276 (Iowa 1974) (maintenance costs of home make award to custodial parent impossible). 
belongs to the spouse who holds title. ${ }^{105}$ At the time of dissolution, however, judges may modify the separate property principle based on consideration of equitable factors, including the length of the marriage, the parties' ages, health, and station, their occupations, the amount and sources of income, vocational skills, employability, the size of the estate, the liabilities and needs of each party, the opportunity of each for future acquisition of capital assets and income, and the contribution of the parties in the acquisition, preservation, or appreciation in value of their respective estates. ${ }^{108}$

A 1976 survey of divorces in Connecticut, ${ }^{107}$ when compared with the California study, ${ }^{108}$ illustrates how differently equal and equitable division schemes affect the disposition of the marital home. The Connecticut study revealed that when houses were jointly held by the divorcing parties (about sixty-eight percent of the cases), the court ordered sale and division in about sixteen percent of the cases, ${ }^{109}$ less than half the rate recorded in California for 1977. 110 The Connecticut study also found that fifteen percent of the women who were awarded the family home were forced to sell it to meet financial obligations. ${ }^{111}$ Comparable data for California indicate that almost two-thirds of the children involved in a divorce had changed their place of residence within three years of the divorce. ${ }^{122}$ If half of this group represents divorces where the home was ordered sold, ${ }^{113}$ a substantial proportion of the remainder must represent families that moved because financial pressures

1051973 Conn. Acts 373 (Reg. Sess.) (codified as amended at Conn. Gen. Stat. Ann. § 46b-81 (West Supp. 1982)).

${ }^{108}$ Conn. Gen. Stat. Ann. \& 46b-81 (West Supp. 1982).

207 Permanent Commission on the Status of Women, State of Connecticut, Marital Dissolution: The Economic Impact on Connecticut Men and Women (1979) [hereinafter cited as Marital Dissolution].

108 See supra notes 86-96 and accompanying text.

109 Marital Dissolution, supra note 107, at 19.

110 Weitzman, supra note 2, at 1205.

11 Marital Dissolution, supra note 107, at 19.

112 See J. Wallerstein \& J. Kelly, Surviving the Breakup: How Children and ParENTS Cope with Divorce 183 (1980). For similar statistics compiled in Massachusetts, see Anderson-Khleif, supra note 6, at 35. Anderson-Khleif's data do not separate awards from eventual sales and therefore cannot be directly compared here. In general, divorced female household heads are likely to move more frequently than the general population. Forty-five percent of Americans over age five changed their residence between 1975 and 1980 . The Numbers News, 5 Am. Demographics Supp. 3 (1982) (figures from the U.S. Census Bureau). But in 1980 , about $75 \%$ of divorced women moved at least once by the end of the third year after marriage ended, and more than one-half moved at least twice by the end of the fourth year. See Office of Policy Dev. \& Research, U.S. DbP'T Of H.U.D., Housing Our Families 3-4 (1980). See also Bane \& Weiss, supra note 4, at 11.

113 See supra note 94 and accompanying text. 
forced them out of the marital home. One can thus infer that under an equitable distribution regime like Connecticut's not only do courts order the sale of the marital home in fewer cases, but sale of the home is the practical result of divorce in fewer cases than under a strict equal division regime like California's.

\section{Special Regimes for the Marital Home}

Because the marital home is often the largest asset of a divorcing couple and because of the unique services that it provides, ${ }^{114}$ the home commands special attention in any system of distribution, equal or equitable. It is only reasonable that a distinct set of rules would surround the home's disposition. ${ }^{115}$ Even in California, in order to preserve the home for the custodial parent and children, courts need not divide marital assets in kind, ${ }^{116}$ though this provision is severely hampered by the equal division requirement. ${ }^{117}$ This part describes various methods by which jurisdictions have provided for special consideration of the marital home, and the comment concludes by comparing the utility and effectiveness of these techniques.

\section{A. The Uniform Marriage and Divorce Act}

The Uniform Marriage and Divorce Act ${ }^{118}$ ("UMDA") sets out two alternative approaches to property division, both within an equitable division framework and both enabling a court to make special provisions for the home. ${ }^{110}$ Alternative $\mathrm{A}$ is recommended for common law jurisdictions ${ }^{120}$ and lists factors to be considered when "equitably apportion[ing]" the property. ${ }^{121}$ In doing so, the court is

124 See supra notes 1-6 and accompanying text.

115 M. GlEndon, supra note 7, at 81 (calling these rules a "special legal regime for the matrimonial dwelling").

${ }_{116}$ See supra notes 30,63 and accompanying text.

117 See supra notes 64-78 and accompanying text.

11 Unir. Marriage and Divorce Act, 9A U.L.A. 91 (1979).

119 Id. $\S 307,9$ A U.L.A. at 142.

${ }^{120}$ Id. Commissioners' Comment, 9A U.L.A. at 144.

121 In making apportionment the court shall consider the duration of the marriage, and prior marriage of either party, antenuptial agreement of the parties, the age, health, station, occupation, amount and sources of income, vocational skills, employability, estate, liabilities, and needs of each of the parties, custodial provisions, whether the apportionment is in lieu of or in addition to maintenance, and the opportunity of each for future acquisition of capital assets and income. The court shall also consider the contribution or dissipation of each party in the acquisition, preservation, depreciation, or appreciation in value of the respective estates, and the contribution of a spouse as a homemaker or to the family unit. 
directed to consider, among other factors, "custodial provisions" and "whether the apportionment is in lieu of or in addition to maintenance." ${ }^{122}$ Alternative $\mathrm{B}^{123}$ is tailored to community property regimes ${ }^{124}$ and explicitly requires that courts consider "the desirability of awarding the family home or the right to live therein for a reasonable period to the spouse having custody of any children." ${ }^{225}$ Both alternatives focus on where and how the custodial spouse and children are to be housed. ${ }^{126}$

Although versions of the UMDA have been adopted in only six states, ${ }^{127}$ alternatives to the Model Act have had a significant impact on other state statutes. ${ }^{128}$ Eleven states statutorily require courts to consider the desirability of awarding the marital home to the spouse receiving custody of the children. ${ }^{128}$ Two other jurisdictions list "custody of the children" as a factor to be considered when dividing the property. ${ }^{130}$ The listed factors are not exhaustive, and all of these statutes permit judges to adjust the property award in favor of the custodial spouse, often with express reference to the children's needs. ${ }^{131}$

In re Marriage of Anderson ${ }^{132}$ illustrates the possible effect of Alternative B's provision that the courts consider "the desirability of awarding the family home ... to the spouse having custody of

Id. (Alternative A), 9A U.L.A. at 142.

122 Id.

123 Id. (Alternative B), 9A U.L.A. at 143.

124 Id. Commissioners' Comment, 9A U.L.A. at 144.

${ }^{125}$ Id. (Alternative B), 9A U.L.A. at 143.

128 Id. § 307.

127 Arizona, Ariz. Rev. Stat. ANn. § 25-318 (1976); Colorado, Colo. Rev. Stat. § 14-10113 (1973 \& Supp. 1982); Illinois, Marriage and Dissolution Act § 503, Ill. Rev. STAT. ch. 40, $\S 503$ (1981); Kentucky, Ky. Rev. Stat. ANN. § 403.190 (Bobbs-Merrill Supp. 1982); Minnesota, Minn. Stat. Ann. $§ 518.58$ (West 1980 \& Supp. 1981); and Montana, Mont. Code ANN. $\S$ 40-4-202 (1981).

${ }^{128}$ See Note, supra note 7, at 448 app. B.

${ }^{129}$ Colorado, Colo. Rev. Stat. § 14-10-113(1)(c) (1973 \& Supp. 1982); Delaware, DeL. Code ANn. tit. 13, § 1513(a)(8) (1974); Illinois, Marriage and Dissolution Act $\S 503$, ILL. Rev. STAT. ch. 40, \& 503(c)(4), (8) (1981); Indiana, IND. Code ANN. § 31-1-11.5-11(b)(3) (Burns 1980); Iowa, Iowa Code Ann. § 598.21(1)(g) (West 1981); Kentucky, Ky. Rev. Stat. Ann. § 403.190(1)(d) (Bobbs-Merrill Supp. 1982); Maine, ME. REv. Stat. Ann. tit. 19, § 722-A(1)(C) (1964); Missouri, Mo. Ann. Stat. \& 452-330.1(3) (Vernon Supp. 1983); New York, N.Y. Dom. REL. LaW § 236(B)(5)(d)(3) (McKinney Supp. 1982); Washington, Wash. Rev. Code ANN. § 26.09.080(4) (Supp. 1983); and Wisconsin, Wis. Stat. Ann. § 767.255(7) (West 1981 \& Supp. 1982).

130 The District of Columbia, D.C. CoDE ANN. \& 16-910(b) (1981 \& Supp. 1982), and Montana, Mont. Code ANN. § 40-4-202(1) (1981).

1s1 See statutes cited supra notes 127, 129-30. Wisconsin is an exception, as it incorporates a presumption of equal division. See supra note 35 and accompanying text.

132541 P.2d 1274 (Colo. Ct. App. 1975). 
any children."13s The Colorado Court of Appeals in Anderson applied the Colorado distribution statute, which embodies Alternative $B,{ }^{134}$ to uphold the award of the marital home to the custodial spouse. The court noted that the child of the divorcing couple "might be further disturbed if forced to move away from the home, neighborhood school, and friends," sion of the property was "within the ambit of the court's discretion" where the court based its order on "the need for the custodial parent to retain the family home" and "the economic circumstances of the parties."136

As an alternative to awarding the marital home to the custodial spouse, the UMDA also suggests granting the custodial spouse the right to live in the home for a reasonable period. ${ }^{197}$ Some courts have achieved this by relying on a trust for sale, leaving the property in possession of the custodial spouse to benefit the children. ${ }^{138}$ Typically, sale of the house depends on some future event (such as the children's majority) at which time the proceeds will be divided between the spouses. ${ }^{139}$

192 Unir. Marriage and Drvorce Act § 307, 9A U.L.A. at 143 (1979).

134 See Colo. REv. Stat. \& 14-10-113 (1973 \& Supp. 1982).

235541 P.2d at 1276.

136 Id. Special equities employed by Florida and West Virginia courts also enable awards of the marital home to the custodial spouse. See, e.g., Duncan v. Duncan, 379 So. 2d 949, 952 (Fla. 1980) (exclusive possession of the home may be granted to support minor children); Power v. Power, 387 So. 2d 546, 548 (Fla. Dist. Ct. App. 1980) ("The award of the residence ... [is] a facet of child support."); Dolch v. Dolch, 368 So. 2d 618, 619 (Fla. Dist. Ct. App. 1979) (order to sell home error when it is unlikely that wife will be able to obtain housing for herself and children from amount yielded from sale); Murredu v. Murredu, 236 S.E.2d 452, 456 (W. Va. 1977) (lower court was correct in awarding house to husband "as a result of his obtaining custody of the children").

197 See Unif. Marriage and Divorce Act § 307 (Alternative B), 9A U.L.A. at 143.

${ }^{198}$ See, e.g., Schuppe v. Schuppe, 69 III. App. 3d 200, 387 N.E.2d 346 (1979) (trust for sale is not unfair); Twardosky v. Twardosky, 113 N.H. 438, 309 A.2d 217 (1973) (trust for sale with possession to wife until remarriage or until youngest child reaches age 18). A trust for sale may rest on beneficial co-ownership of the property or upon a settlement that entitles the noncustodial spouse to a future interest in the property. For discussion of this type of award and its application to the marital home, see Forrest, Trusts for Sale and Co-ownership-A Case for Reform, 42 Conv. \& Prop. LAw. '(n.s.) 194 (1978); Hayes \& Battersby, Property Adjustment Orders and the Matrimonial Home, 45 Conv. \& Prop. LAw. (n.s.) 404 (1981); and Miller, Sale of the Matrimonial Home, 42 Conv. \& Prop. Law. (n.s.) 301 (1978).

199 See, e.g., Brandenburg v. Brandenburg, 617 S.W.2d 871 (Ky. Ct. App. 1981) (setting out an elaborate formula for division of the proceeds); Brugger v. Brugger, 303 Minn. 488, 492, 229 N.W.2d 131, 134 (1975) (trust for sale imposed with "the provisions for child support and the use of the homestead and its ultimate sale ... taken into account in balancing other portions of judgment"). 


\section{B. Great Britain}

In Great Britain a separate legal regime for the marital home is already acknowledged in principle ${ }^{\mathbf{1 4 0}}$ and clearly articulated in case law. ${ }^{141}$ The Matrimonial Causes Act ("M.C.A."), which governs property distribution upon divorce, is of the equitable distribution variety and leaves ample room for judicial discretion. ${ }^{142}$ The tools of distribution are like those of American jurisdictions: sale and division, trust for sale, and outright award, ${ }^{143}$ but English courts have focused more clearly on the needs of the parties, particularly on the children's needs. Two guiding principles based on needs have emerged in recent English cases: (1) adequate provision should be made to ensure support and accommodation of the children of the marriage, and (2) some provision should be made to meet the needs of each spouse when those needs have been occasioned by the marriage breakdown. ${ }^{144}$ The courts have emphasized these needs above the property rights of the parties, especially in

140 See Eekelaar, Some Principles of Financial and Property Adjustment on Divorce, 95 LAw Q. REv. 253, 253-57 (1979).

141 See infra notes 146-60 and accompanying text.

${ }^{142}$ Matrimonial Causes Act, 1973, ch. 18, $\$ 25$. The M.C.A. lists the following factors to guide judges in making property adjustment orders:

(a) the income, earning capacity, property and other financial resources which each of the parties to the marriage has or is likely to have in the foreseeable future;

(b) the financial needs, obligations and responsibilities which each of the parties to the marriage has or is likely to have in the foreseeable future;

(c) the standard of living enjoyed by the family before the breakdown of the marriage;

(d) the age of each party to the marriage and the duration of the marriage;

(e) any physical or mental disability of either of the parties to the marriage;

(f) the contributions made by each of the parties to the welfare of the family, including any contribution made by looking after the home or caring for the family;

$(\mathrm{g})$ in the case of proceedings for divorce or nullity of marriage, the value to either of the parties to the marriage of any benefit (for example, a pension) which, by reason of the dissolution or annulment of the marriage, that party will lose the chance of acquiring.

Id.

143 Id. § 24.

14 Eekelaar, supra note 140, at 256. Eekelaar argues that courts have followed these principles in derogation of the "minimal loss" principle written into $\S 25$ of the M.C.A. Id. at 5, 267-69. This principle requires that the court "place the parties so far as is practicable . . . in the position in which they would have been if the marriage had not broken down and each had properly discharged his or her obligations and responsibilities to the other." M.C.A. $\S 25(1)$. There is no counterpart to this clause in the American UNIF. MarRIAGE AND Drvorce ACr (1979). The minimal loss principle has been much criticized, see, e.g., Eekelaar, supra note 140, at 255-56, 261-62, and a recent Law Commission report recommends its abolition. Law Commission, The Financial Consequences of Divorce 7 (1981) (No. 112). 
determining the disposition of the marital home. ${ }^{145}$ As one English court explained,

whenever a court is dealing with families of limited resources, "needs" are likely to be much more important than resources, when it comes to exercising discretion. In most individuals and most families the most urgent need is a home. It is therefore to the provision of homes for all concerned that the courts should direct their attention in the first place. ${ }^{148}$

The emphasis on needs has also led many courts to reject the notion of a "clean break,"147 or final financial settlement upon divorce. For example, in Moore $v$. Moore, ${ }^{148}$ the court held that the clean break principle should not be adopted in cases in which a continuing link between the parties exists through children or in situations in which one of the parties would have to obtain support from the state. ${ }^{148}$

The English courts have stressed the importance of the home to adequate child support to the extent that "it is now a common feature of dissolution proceedings for the property rights eventually to be adjusted so as to give priority to the accommodation of the spouse who is looking after the children."150 The courts have implemented this goal with the device of a trust for sale. Both parties retain beneficial ownership in the home, but the custodial spouse has possession during their children's minority. ${ }^{181}$ This

145 See Freeman, When Marriage Fails-Some Legal Responses to Marriage Breakdown, 31 Current Legal Probs. 109, 128-29 (1978).

${ }^{146}$ Browne v. Pritchard, [1975] 1 W.L.R. 1366, 1371 (C.A.) (Ormrod, L.J.). In this case the wife had remarried and the husband was living in the marital home with two children from a previous marriage. The wife claimed the house should be sold and the proceeds divided equally. Id. at 1367 . The court determined that to do so would deprive the husband and his children of suitable housing and concluded that "to order the sale of this house now could properly be described as socially disastrous, if not irresponsible. Therefore the sale must be postponed." Id. at 1371.

${ }^{347}$ See, e.g., Minton v. Minton, 1979 A.C. 593 (1978); Dunford v. Dunford, [1980] 1 W.L.R. 5 (C.A. 1979). See also LAw Commission, supra note 144, at 11 ("II]t must be accepted that the occasions on which it is possible for the parties to arrive at a final, once and for all settlement, on the occasion of their divorce will be comparatively few, and almost non-existent when there are young children.").

148 The Times (London), May 10, 1980, at 7, col. 1 (C.A. 1980).

149 Id.

${ }^{160}$ Bassett v. Bassett, [1975] 2 W.L.R. 270, 280 (C.A. 1974).

${ }^{251}$ See, e.g., Browne v. Pritchard, [1975] 1 W.L.R. 1366 (C.A.) (sale six months after youngest child reaches 18); Allen v. Allen, [1974] 1 W.L.R. 1171 (C.A.) (sale postponed until younger child reaches 17 or finishes full-time education, whichever occurs earlier); Chamberlain v. Chamberlain, [1973] 1 W.L.R. 1557 (C.A.) (sale upon completion of children's educaton); Hector v. Hector, [1973] 1 W.L.R. 1122 (C.A.) (sale postponed until child reaches age 16). This type of award and its consequences are discussed in Hayes \& Battersby, supra 
technique is called a "Mesher order"162 after Mesher v. Mesher, one of the first cases to order such an arrangement. In Mesher itself, the wife had remained with the couple's child in the marital home. To avoid depriving the husband of his property interest but at the same time to provide housing for the wife and child, the court imposed a trust for sale. ${ }^{154}$ Similarly, in Harvey $v$. Harvey ${ }^{165}$ the court reconciled the competing property rights of the spouses with the children's need for a home by means of a Mesher order. The court justified its order by referring to the parties' initial intent when they invested in the home:

[T] his asset would never have been available to either of the parties as a capital or income producing asset as such, whilst they both survived and whilst their marriage subsisted .... They would not have had the asset to realize during the currency of their marriage unless they had both agreed to obtain less expensive accommodation after their family had grown up and left them. ${ }^{156}$

The court concluded that the sale should be postponed for the wife's lifetime, with an occupation rent to be paid to the husband after the children's emancipation. ${ }^{157}$

The English courts and Parliament are still developing techniques to resolve the tension between the needs approach and property rights, ${ }^{158}$ but the British recognition of the special nature of the marital home among marital properties seems well established. ${ }^{159}$ According to Lord Denning,

note 138, at 407-14. Two other types of orders are frequently directed at the marital home upon divorce. One is a charge order, which resembles a trust for sale with the exception that it does not reflect a real interest in the property. The nonresident spouse has merely a security interest in the home. The second type of arrangement is a settlement order, which settles the property upon the custodial spouse and a future interest upon the noncustodial party. A trust for sale may also be imposed as part of a settlement order, but a settlement need not rest on beneficial co-ownership of the property. See Hayes \& Battersby, supra note 138, at 414-22.

${ }^{132}$ See, e.g., Eekelaar, supra note 140, at 257.

183 [1980] 1 All E.R. 126 (C.A. 1973).

154 Id. at 128. Before Mesher the idea of a trust for sale had been rejected in Jones v. Challenger, [1961] 1 Q.B. 176. The court there ruled that the purpose of the marital home was at an end when the marriage ended. Id. at 183.

${ }^{185}$ [1982] 1 All E.R. 693 (C.A.).

158 Id. at 696 .

187 Id. at 697 .

163 See M. GLEndon, supra note 7, at 84. See also LAw Commission, supra note 144, at 7-9 (tension between certainty and flexibility).

158 The development of mechanisms to sidestep property rights and award the home based on needs indicates the trend in Anglo-American law toward a separate legal regime 
[w] hen judges are dealing with the matrimonial home, they nowadays have great regard to the fact that the house is bought as a home in which the family is to be brought up. It is not treated as property to be sold, nor as an investment to be realised for cash. ${ }^{160}$

The widespread view that the home should be awarded based upon the children's needs is further reinforced by a recent Law Commission report recommending that the needs of children be established as a priority in financial orders upon divorce. ${ }^{\mathbf{1 6 1}}$

\section{Maryland}

In 1978, Maryland adopted a domestic relations law that clearly established a separate legal regime for the marital home. ${ }^{162}$ Under the law, Maryland courts are disabled from changing title to property $^{163}$ but may achieve an equitable distribution of property acquired during the marriage by providing a monetary award to reflect an equal division of the value of the marital property. ${ }^{164}$ The act, however, separates the marital home and "family use per-

for the marital home. Glendon describes this as part of a similar shift within most family property systems. Swedish law, for example, permits an award of the house to the one who needs it most, usually the custodial parent. In France, a home held as separate property by one spouse may be subjected to a lease in favor of the other if the latter retains custody of the children. M. GLENDON, supra note 7, at 81 n.114.

The trust for sale may persist for some time in England, as a bill that would have provided a statutory basis for co-ownership of the marital home died in Parliament in February 1980. Temkin, Property Relations During Marriage in England and Ontario, 30 INT'L \& Comp. L.Q. 190, 199-200 (1981). See also Murphy \& Rawlings, The Matrimonial Homes (Co-Ownership) Bill: The Right Way Forward?, 10 FAM. L. 136 (1980) (discussing the proposed bill). Meanwhile, the strong pull of prima facie fairness is assuaged by recourse to a "one-third" rule, see Gengler v. Gengler, [1976] 1 W.L.R. 275 (Fam.); Wachtel v. Wachtel, 1973 Fam. 72 (C.A.), establishing a presumption that each spouse is entitled to one-third of the marital property. The rule has been criticized for being inadequate to accommodate the parties' needs and too infeasible to adapt to all financial problems. See, e.g., Chamberlain v. Chamberlain, [1973] 1 W.L.R. 1557, 1562-64 (C.A.); Cann v. Cann, [1977] I W.L.R. 938, 94042 (Fam. 1976); Smith v. Smith, [1975] 2 All E.R. 19, 22 (Fam.). But see Green, The Divorce Debate, 1980: Fresh Thoughts on Ironing Out the Maintenance Muddle, The Times (London), June 27, 1980, at 17e (describing the Wachtel rule as a useful rule of thumb).

${ }^{160}$ Williams v. Williams, [1977] 1 All E.R. 28, 30 (C.A. 1976).

161 Law Commission, supra note 144, at 9.

182 Act of May 29, 1978, ch. 794, $1978 \mathrm{Md}$. Laws 2304 (codified in relevant part at MD. CTs. \& Jud. Proc. Code ANN. \$§ 3-6A-01 to -07 (1980)). For a discussion of the 1978 law and the changes it brought to Maryland domestic relations law, see Legislation-Property Disposition Upon Divorce in Maryland: An Analysis of the New Statute, 8 U. BaLT. L. REv. 377 (1979).

${ }_{163}$ Md. Cts. \& Jud. Proc. Code Ann. §§ 3-6A-03(a), 3-6A-04(a) (1980).

164 Id. § 3-6A-05. 
sonal property"168 from other marital assets and gives the courts discretion to grant a use and possession award of the former assets for up to three years to the custodial spouse. ${ }^{186}$ In exercising this discretion, courts must consider the best interests of any minor children and the spouses' interests in the home as a dwelling place and as an investment. ${ }^{167}$

A recent decision by the Maryland Court of Appeals ${ }^{168}$ lists the benefits intended by the Maryland statute. The court affirmed the trial court's order of use and possession to the custodial spouse during the period after the filing for divorce and prior to the final divorce decree. The court rejected a due process challenge to the statute in part because of the state's interest in child welfare, relying on the legislature's stated goal in enacting the section to give "particular and favorable attention"169 to the needs of children.170 The court found that "[t] he procedure provided for in [the statute] seeks to avoid uprooting the children from the home, school, social and community setting upon which they are dependent, especially during the period of parental separation."171

Even so, the statute falls short of a solution to the problem of accommodating the children's needs upon divorce because the judicial discretion to recognize those needs is limited to a three-year award and restricted to a "use and possession" arrangement.

168 "Family use personal property" is defined as "tangible personal property, acquired during the marriage, owned by either spouse or owned jointly by both spouses, and used primarily for family purposes." Id. § 3-6A-01(c). Maryland courts also have power to determine possession of the property regardless of title, id. § 3-6A-06(c)(1), and to make orders for payment of mortgage, maintenance, insurance, taxes, and other expenses connected with the property, id. \& 3-6A-06(c)(2).

168 Id. \$ 3-6A-06.

${ }^{167}$ Id. $\$ 3-6 \mathrm{~A}-06$ (a) directs courts to determine occupancy of the home with reference to the following factors:

(1) The best interests of any minor child;

(2) The respective interest of each spouse in continuing to use the family use personal property or occupy or use the family home or any portion of it as a dwelling place;

(3) The respective interest of each spouse in continuing to use the family use personal property or occupy or use the family home or any part of it for the production of income;

(4) Any hardship imposed upon the spouse whose interest in the family home or family use personal property is infringed upon by an order issued under this section. The statute's preamble states that "if there are minor children in the family, their interest must be given particular and favorable attention." Id. preamble.

16s Pitsenberger v. Pitsenberger, 287 Md. 20, 410 A.2d 1052 (1980).

169 See supra noie 167.

$170287 \mathrm{Md}$. at $30-33,410 \mathrm{~A} .2 \mathrm{~d}$ at 1058-60.

${ }^{171}$ Id. at $31,410 \mathrm{~A} .2 \mathrm{~d}$ at 1059. 


\section{Discussion}

For the purpose of making the marital home available to meet the needs of the custodial parent and children, the studies undertaken in California suggest that there is little to recommend absolute equality. The wide discretion available under an equitable division regime avoids the inflexibility inherent in a requirement of equal division.

When the New York legislature considered an equitable division bill patterned after the UMDA, ${ }^{172}$ however, supporters of a bill requiring a presumption of equality suggested that equitable distribution would result in a species of inequality and an increase in litigation. Inequality, they argued, would arise from the unequal treatment of like cases at the hands of different judges. ${ }^{173}$ This is probably true, but it seems both unremarkable and unavoidable; the same type of inequality is present in a presumption of equality, since rebutting either presumption would entail balancing the same factors. Even when strictly equal division is required, moreover, different judges will accept different valuations of the assets at issue. ${ }^{174}$ Finally, it may be an equally objectionable species of inequality to treat dissimilar cases identically. When equal division is required or presumed because of a general principle of partnership in marriage and equality in property division, individuals' needs for the home may be disregarded even when the marriage was not a partnership and the spouses' post-divorce needs are not the same.

In support of the argument that the equitable division rule might increase litigation, it was suggested that parties unsure of how much they might get in court in an equitable division would be more likely to take a chance and litigate. A presumption of equality, on the other hand, would encourage only those with substantial property or an overwhelming case to pursue litigation. ${ }^{175}$ Yet a presumption of equality would not necessarily discourage litigation because both the application of the presumption and the actual division might be challenged. And if a presumption of equality would reduce litigation, it might do so at the expense of fairness-parties with neither substantial property nor an overwhelming case may nevertheless have a need for unequal division of property. The need for the home, moreover, may rest primarily

\footnotetext{
172 See generally supra notes 50, 52 and accompanying text.

173 See Sassower, supra note 52.

174 See supra note 96.

${ }^{178}$ See Sassower, supra note 52.
} 
with the children and not with the parties at all. By employing a presumption in favor of equality, one relies in effect on the parties to raise the issue of special treatment of the home. Such reliance is likely misplaced, since divorce is a time of emotional stress and financial pressure.

Though on balance the UMDA's equitable division seems to provide a preferable framework for decisions regarding the marital home, its uncertainty is admittedly a problem. ${ }^{176}$ Certainty is important because only a very small percentage of divorces are settled in court, ${ }^{177}$ and it may be that "the primary function of contemporary divorce law [is to] . . . provid[e] a framework for divorcing couples themselves to determine their respective rights and responsibilities after dissolution."178 Legal rules are a starting point for divorcing parties bargaining in the shadow of the law: ${ }^{179}$ "The legal rules governing alimony, child support, marital property and custody give each parent certain claims based on what each would get if he or she simply went to court and had the court impose some allocation."180 If legal rules are uncertain, the weaker party will have little bargaining power with a greater risk of inequitable settlement.

Though uncertainty is a legitimate objection to the equitable division statutes as they have been applied in the United States, the evidence from Great Britain illustrates that judges can exercise statutory discretion in a predictable way to maximize the interests of the children of the marriage when awarding the home. ${ }^{181} \mathrm{En}$ glish judges have articulated clear goals that guide home awards and minimize uncertainty. The guiding principles remain unlegislated, though they are under consideration in Parliament. ${ }^{\mathbf{1 8 2}}$

176 See supra notes 18-57 and accompanying text. The outer limits of the wide discretion allowed by equitable division were reached in December 1981, when a county court in Michigan (not a UMDA state) awarded the marital home to the children of the marriage, giving the divorcing parents visitation rights. Church v. Church, 8 FAM. L. REP. (BNA) 1070 (Mich. Cir. Ct. App. Dec. 11, 1981). In the aftermath the parties expressed their satisfaction with the arrangement. See Wichita Eagle-Beacon, Jan. 20, 1982, at 3A, col. 2.

${ }^{177}$ It has been estimated that courts see only 10 to $12 \%$ of the divorces of parties with children. Wallerstein, The Child in the Divorcing Family, JudGes' J., Winter 1980, at 16, 18.

178 R. Mnookin, Bargaining in the Shadow of the Law: The Case of Divorce 1 (Working Paper No. 3, Centre for Socio-Legal Studies, Oxford University, February 1979). Mnookin's detailed study of private ordering in family law identifies four factors that operate to order private divorce settlements: 1) party preferences, 2) the rules of law, 3) the uncertainty of these rules, and 4) transaction costs. Id. at 15.

179 Id. at 18.

${ }^{180} \mathrm{Id}$.

181 See supra notes $140-61$ and accompanying text.

183 See supra note 159. 
The British system allows judges to define their goals without check and to refine the mechanisms toward their chosen ends. In the case of the marital home, judges have focused on children's needs and have developed the Mesher order to meet them. ${ }^{183}$ The extent to which precedent binds judges to these goals is not clear, however, and uncertainty therefore persists. This uncertainty may inhibit challenges from parties who are dissatisfied with court awards, and it dilutes the notice to parties settling out of court.

The Maryland statute represents an American response to the uncertainty problem. The statute treats the marital home independently of other property, but it falls short of a solution to children's needs on divorce. Judicial discretion to recognize those needs is limited to a three-year award restricted to a "use and possession" arrangement. If the children are small or the family is large, three years may be hardly enough time for the custodial parent to care for the children, train for a job, and arrange for alternative housing. The Maryland statute gives parties a high degree of certainty but frustrates attempts to provide for children's needs beyond the legislatively imposed limits. ${ }^{184}$

\section{CoNCLUSION}

The unique nature of the marital home argues for a separate legal regime for the disposition of that property upon divorce. There is evidence that such a regime is developing in Anglo-American equitable distribution systems, primarily in recognition of children's needs. Attempts to develop effective separate rules for the home in equal division states have been less successful. Data compiled in California indicate that many homes are sold in compliance with the state's equal division requirement, which suggests that in such a rigid framework judges cannot effectively take account of the special needs of the children and the custodial parent.

Though equitable distribution systems are less susceptible to criticism on grounds of inequity, a system which relies on judicial discretion lacks certainty. Certainty in legal rules is crucial, since only a small percentage of divorces are decided in court. The British experience demonstrates, however, that equity and certainty are not incompatible. In Britain, judges have articulated needs

18s See supra notes 150-57 and accompanying text.

184 Weitzman, supra note 2, has recommended legislative adoption of a presumption that the home be awarded to the custodial parent. Id. at 1266 . Such a presumption could be made contingent on a financial arrangement that would allow the custodial parent to keep the home. 
principles which inject predictability into home awards; the children's interests will thus be maximized. It is unclear whether the British practice can be transplanted to the United States. Under similar equitable distribution statutes, courts in most states have been reluctant to set out clear goals, perhaps fearful of being accused of judicial lawmaking. The most prominent legislative attempt to balance needs with certainty, the Maryland statute, seems to have erred on the side of certainty.

The statutory developments that reveal these problems in marital law are recent, and quick responses run the risk of aggravating the unfairness of divorce. Nevertheless, once one comprehends the seriousness with which children's needs should be considered and the superficial fairness of equal division, it becomes apparent that equal division should be rejected and that systems which can respond to parties' needs should be pursued. 